\title{
ASSOCIATIONS BETWEEN POLYMORPHISM OF GROWTH HORMONE GENE WITH MILK PRODUCTION, FAT AND PROTEIN CONTENT IN FRIESIAN HOLSTEIN CATTLE
}

\author{
T. Hartatik ${ }^{1}$, D. Kurniawati ${ }^{2}$ and Adiarto ${ }^{1}$ \\ ${ }^{1}$ Faculty of Animal Science, Gadjah Mada University, \\ Jl. Fauna No. 3, Bulaksumur Yogyakarta 55281 -Indonesia \\ ${ }^{2}$ Faculty of Agriculture, Lampung University, \\ Jl. Prof. Dr. Sumantri Brojonegoro No. 1, Bandar Lampung 35145 - Indonesia \\ CorrespondingE-mail: tety@ugm.ac.id
}

Received July 15, 2015; Accepted August 26, 2015

\begin{abstract}
ABSTRAK
Penelitian ini bertujuan untuk menganalisis hubungan polimorfisme gen hormon pertumbuhan (leu/val) dan produksi susu pada sapi Friesian Holstein. Sampel penelitian berasal dari 62 ekor sapi yang diambil dari dua kelompok sapi Friesian Holstein (dari New Zealand=19 ekor and Australia=43 ekor). Polymerase Chain Reaction (PCR) yang dilanjutkan dengan Restriction Fragment Length Polymorphism (RFLP) menggunakan enzim restriksi AluI untuk menentukan genotip sapi. Genotip ditentukan berdasarkan target gen GH 211 bp yang terletak pada intron 4 dan exon 5 dari gen hormon pertumbuhan. Genotypes Leu/Leu (LL) pada kedua grup menunjukkan frekuensi yang lebih tinggi dibandingkan dengan genotip Leu/Val (LV). Sapi Friesian Holstein dari New Zealand memperlihatkan genotip LL dan LV sebesar $84 \%$ dan 16\%. Sapi Friesian Holstein dari Australia memiliki genotip LL dan LV sebesar $79 \%$ and $21 \%$. Hubungan antara polimorfisme Leu/Val pada gen hormon pertumbuhan terhadap produksi susu, kadar lemak dan protein tidak menunjukkan pengaruh yang nyata pada kedua grup. Berdasarkan pengelompokan asal sapi, hasil penelitian menunjukkan perbedaan yang nyata pada kadar lemak dan protein susu. Kadar lemak dan protein susu pada sapi FH yang diimpor dari Australia lebih tinggi dibandingkan dengan kadar lemak dan protein susu pada sapi FH yang diimpor dari New Zealand.

Kata kunci: Friesian Holstein import, gen hormon pertumbuhan, produksi susu, kadar lemak dan protein
\end{abstract}

\begin{abstract}
The aim of the research was to determine the associations between polymorphism of the bovine growth hormone $(\mathrm{GH})$ gene $(\mathrm{Leu} / \mathrm{Val})$ and milk production of Friesian Holstein Cattle. A total of 62 cows which consist of two Friesian Holstein cattle groups (from New Zealand=19 heads and Australia $=43$ heads) were used for the research. We performed the Polymerase Chain Reaction and followed by Restriction Fragment Length Polymorphism using AluI restriction enzyme. The genotype was observed base on the target gene GH $211 \mathrm{bp}$ in the part of intron 4 and exon 5 of growth hormone gene. The frequencies of genotypes LL were found higher than genotype LV in both groups. Friesian Holstein cattle from New Zealand showed the genotype LL and LV as $84 \%$ and $16 \%$, respectively. Friesian Holstein cattle from Australia show the genotype LL and LV as 79\% and 21\%, respectively. The association between Leu/Val polymorphism on milk production, fat and protein content in both groups did not show the significant effect. Base on two groups of the origin of cattle, the result showed the significant different on fat and protein content of milk. Fat and protein contents of milk were higher in breed of FH imported from Australia compared to those in breed of FH imported from New Zailand.

Keywords : imported FH, growth hormone gene, milk production, fat and protein content
\end{abstract}




\section{INTRODUCTION}

The selection of dairy cattle can be focused on the yield and composition of milk. Recently, the potential candidate genes related to milk production have been widely recognized. The candidate genes are selected on the basis of known relationships between physiological or biochemical processes. The variation of allelic genes in the regulatory and structural regions of those genes may influence the diversification of quantity and composition of milk. One of the candidate genes is growth hormone $(\mathrm{GH})$ gene. Bovine growth hormone gene consists of five exons separated by interval introns. This polymorphism was localized in the exons $\mathrm{V}$ of the gene in position 2141 (Lucy et al., 1993). The previous study detected a polymorphic site located in the exon $\mathrm{V}$ of the $\mathrm{GH}$ gene (transversion $\mathrm{C} \rightarrow \mathrm{G}$ in position 2141 of the gene) and consequently the substitution of Leu by $\mathrm{Val}$ in a protein product (Lucy et al., 1993). The other finding also reported the polymorphism in the exon $\mathrm{V}$ of the GH gene, in position 2241 showed the transversion from A $\rightarrow$ C (Yao et al., 1996). The additional polymorphic site in the somatotropin gene (point mutation $\mathrm{C} \rightarrow \mathrm{T}$ in the codon 172) was found in the Japanese cattle and consequently threonine was changed into methionine in a protein chain (Chikuni, 1994). The studies on the influence of the Leu/Val polymorphism on production traits were quite advanced but the results obtained by various researchers were not always corresponding. Friesian Holstein cows homozygous for Leu-127 of bGH produced more milk compared with Leu/Val animals (Lucy et al., 1993). The aim of this study was to investigate the allelic frequencies at the Leu/Val locus at the bovine $\mathrm{GH}$ gene Frisian Holstein cattle and the relationship of polymorphism growth hormone gene with milk production, fat and protein content.

\section{MATERIALS AND METHODS}

\section{Sample and Data Collection}

The total numbers of samples were 62 heads of Friesian Holstein (FH) cattle at Balai Pembibitan Ternak Unggul Hijauan Pakan Ternak (BPTU-HPT) Baturraden-Purwokerto. The samples consisted of 19 heads FH imported from New Zealand and 43 heads FH imported from Australia. The secondary data of milk yield, fat and protein content were also collected.

\section{DNA Extraction and Amplification of 211 bp GH Gene}

About $3 \mathrm{~mL}$ of blood sample were collected from 62 animals. The genomic DNA was extracted from blood samples using extraction method described by Sambrook et al. (1989). A $211 \mathrm{bp}$ fragment of GH gene was amplified with the primer of GH-forward: 5'GCTGCTCCTGAGGGC-CCTTC-3', and the primer of GH-reverse: 5'CATGACCCTCAGGTACGTCTCCG-3' (Reis et al., 2001). Amplification of 211 bp of $\mathrm{GH}$ gene were conducted by using thermal cycler machine (Peqlab, Advanced Primus 25, Germany). The PCR condition was programmed for initial denaturation at $95{ }^{\circ} \mathrm{C}$ for 5 minutes, followed by 35 cycles of denaturation at $95^{\circ} \mathrm{C}$ for 30 seconds, annealing at $65{ }^{\circ} \mathrm{C}$ for 30 seconds, extention at 72 ${ }^{\circ} \mathrm{C}$ for 30 seconds, then followed by final extention at $72{ }^{\circ} \mathrm{C}$ for 5 minutes (Mu'in, 2008).

\section{Restriction Fragment Length Polymorphism}

The $211 \mathrm{bp}$ product size of $\mathrm{GH}$ gene was digested with AluI enzyme at $37^{\circ} \mathrm{C}$ for three hours to identify the polymorphism of GH gene. The digestion products were separated by electrophoresis using $2.5 \%$ agarose gels in 1XTBE buffer and running with $50 \mathrm{~V}$ for an hour for separation of the DNA fragments. The agarose gels were stained with ethidium bromide in order to visualize the DNA fragments by UV light. The size of the DNA fragments were compared with DNA marker $\phi X 174$ DNA/BsuRI (HaeIII) (Fermentas).

\section{Genotype, Allel Frequency and Data Analysis}

Genotyping base on Leu/Val polymorphism of GH gene was obtained from the results of digestion of each sampel with AluI restriction enzyme. Three patterns (genotypes) were produced as the result of AluI restriction site (AGCT) such as VV (211 bp), LV (211, 159 and $52 \mathrm{bp}$ ) and LL (159 and $52 \mathrm{bp)}$ band pattern could be distinguished on the gel (Hartatik et al., 2013; Mu'in, 2008).

\section{RESULTS AND DISCUSSION}

Growth hormone, encoded by the GH gene, modulates growth and lactation in domestic animals, and then genetic variants at the GH locus might affect its level stage or tissue of expression, as well as its functions, having an impact on production traits. The restriction fragment length 
polymorphism of growth hormone product was digested using AluI restriction enzyme showed the DNA band as 159 and $52 \mathrm{bp}$ (Leu/Leu genotype) and the DNA band as 211, 159 and $52 \mathrm{bp}$ (Leu/Val genotype (Figure 1). It was found $79 \%$ to $81 \%$ Leu/Leu genotype in this study. The frequency of the Leu allele (CTG) was higher than Val allele (GTG). Friesian Holstein cattle from New Zealand have 92\% Leu allel and $8 \%$ Val allele. Friesian Holstein cattle from Australia have 90\% Leu allel and 10\% Val allele (Table 1).

The frequencies of Leu/Val alleles in this study were similar to the frequencies of the same allele in earlier study for Friesian Holstein cattle. Higher frequency of the Leu allele was mostly observed in the Holstein breed (Lucy et al., 1993; Reis et al., 2001; Mu'in, 2008; Lee et al., 1996; Zhang et al., 2007; Sabour et al., 1997; Vukasinovic et al., 1999; Dario et al., 2005; Pawar et al., 2007; Mu'in and Zurahmah, 2007; Mohammadabadi et al., 2010). Leu allele is a common allele in growth hormone gene. Based on the observed vs. expected genotype frequencies the whole pool was in Hardy-Weinberg genetic equilibrium $\left(\mathrm{X}^{2}=1.04\right)$. Total samples of 50 animals from 62 animals had homozygote Leu/leu alleles. The allele frequencies of total sample showed the same result for that of Australia sample (0.90 Leu and $0.10 \mathrm{Val})$. This similarity was due to the proportion of sample and the frequency of each genotype. Two digits of calculation in decimal were also influencing the result $(0.903$ vs 0.895$)$.

Table 2 represents the differences of fat content and protein content between Friesian Holstein cattle imported from New Zealand and Australia. However there is no significant effect of genotype with milk production, fat and protein content in both Frisian Holstein cattle. This result may be influenced by the condition of management in BPTU-HPT Baturaden had the standard of feeding with minimum requirements for cattle. So, the function of potential genetic in cattle cannot be optimized. On the other hand, the results of statistical analysis showed statistically differences $(\mathrm{P}<0.05)$ between the mean values of

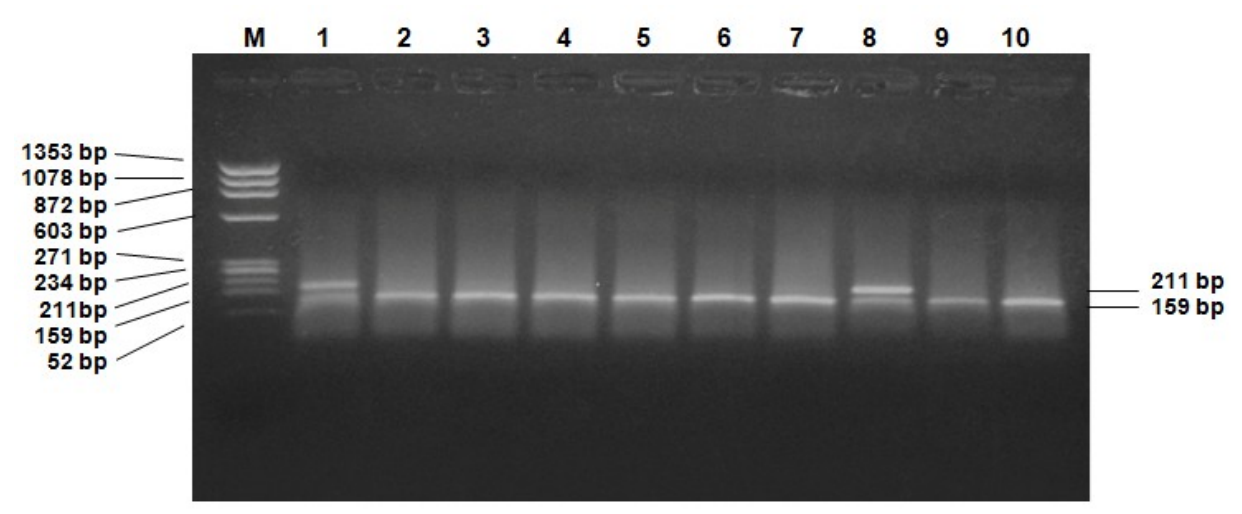

Figure 1. Representative Result of GH-Alu I Analysis Detected by Agarose Gel Electrophoresis. M=DNA Marker $\phi X 174 /$ BsuRI(HaeIII); 1-10: PCR-RFLP GH-Alu I

Table 1. Frequencies of Genotypes and Alleles of the GH Gene

\begin{tabular}{lccccccc}
\hline \multirow{2}{*}{ FH imported } & & \multicolumn{3}{c}{ Genotypes } & & \multicolumn{2}{c}{ Alleles } \\
\cline { 7 - 8 } & $\mathrm{N}$ & LL & LV & VV & & L & V \\
\hline New Zealand & 19 & 0.84 & 0.16 & 0.00 & & 0.92 & 0.08 \\
Australia & 43 & 0.79 & 0.21 & 0.00 & & 0.90 & 0.10 \\
Total sampel & 62 & 0.81 & 0.19 & 0.00 & & 0.90 & 0.10 \\
\hline
\end{tabular}

N: The number of samples; L; Leu; V: Val 
Table 2. Association of the Leu/Val Genotype with Milk Production, Fat and Protein Content in the FH Cows

\begin{tabular}{|c|c|c|c|c|c|}
\hline Parameter & Type & Genotype & $\mathrm{N}$ & $\begin{array}{c}\text { Average Value } \\
\text { of Each Genotype }\end{array}$ & $\begin{array}{r}\text { Average Value } \\
\text { of Each Breed }\end{array}$ \\
\hline \multirow{3}{*}{$\begin{array}{l}\text { Milk Production } \\
(\mathrm{x} 1000, \mathrm{~L})\end{array}$} & NZ & LL & 16 & $4.00 \pm 1.56$ & \multirow[t]{2}{*}{$4.18 \pm 1.49$} \\
\hline & & LV & & $5.19 \pm 0.23$ & \\
\hline & $\mathrm{AU}$ & $\begin{array}{l}\text { LL } \\
\text { LV }\end{array}$ & $\begin{array}{r}34 \\
9\end{array}$ & $\begin{array}{l}5.66 \pm 1.83 \\
5.79 \pm 1.49\end{array}$ & $5.68 \pm 1.79$ \\
\hline \multirow[t]{2}{*}{ Fat content $(\%)$} & NZ & $\begin{array}{l}\text { LL } \\
\text { LV }\end{array}$ & $\begin{array}{r}16 \\
3\end{array}$ & $\begin{array}{l}3.98 \pm 0.64 \\
4.04 \pm 0.26\end{array}$ & $3.99^{\mathrm{a}} \pm 0.59$ \\
\hline & $\mathrm{AU}$ & $\begin{array}{l}\text { LL } \\
\text { LV }\end{array}$ & $\begin{array}{r}34 \\
9\end{array}$ & $\begin{array}{l}4.74 \pm 0.76 \\
4.93 \pm 0.59\end{array}$ & $4.78^{\mathrm{b}} \pm 0.72$ \\
\hline \multirow[t]{2}{*}{ Protein content $(\%)$} & $\mathrm{NZ}$ & $\begin{array}{l}\text { LL } \\
\text { LV }\end{array}$ & $\begin{array}{r}16 \\
3\end{array}$ & $\begin{array}{l}2.94 \pm 0.06 \\
2.95 \pm 0.07\end{array}$ & $2.94^{c} \pm 0.66$ \\
\hline & $\mathrm{AU}$ & $\begin{array}{l}\text { LL } \\
\text { LV }\end{array}$ & $\begin{array}{r}34 \\
9\end{array}$ & $\begin{array}{l}3.23 \pm 0.39 \\
3.23 \pm 0.47\end{array}$ & $3.23^{\mathrm{d}} \pm 0.40$ \\
\hline
\end{tabular}

$\mathrm{a}, \mathrm{b}$ : significant different $(\mathrm{P}<0,05)$ in fat content of different breed; ${ }^{c}$,d: significant different $(\mathrm{P}<0,05)$ in protein content of different breed; NZ: New Zealand ; AU: Australia; LL: Leu/Leu ; LV: Leu/Val

fat and protein content in studied population of Friesian Holstein cattle imported from New Zealand and Australia. Lucy et al. (1993) reported that $\mathrm{L}$ allele was closely related with higher milk production traits for Holstein cattle, whereas in Jersey the $\mathrm{V}$ allele was associated with higher milk yield.

\section{CONCLUSION}

Polymorphism of Growth Hormone in AluI site restriction showed non-significant effect of milk yield, fat and protein content. However, different breed of Frisian Holstein cattle imported from New Zealand and Australia significantly influenced the yield of fat and protein content, but not for milk yield. Fat and protein contents were higher in breed of FH imported from Australia compared with those in breed of $\mathrm{FH}$ imported from New Zailand.

\section{ACKNOWLEDGMENT}

The authors wish to express thanks to Head of BPTU-HPT Baturraden for permitting the research. This study was partly supported by Research Grant 2013 from Graduate School
Program, Faculty of Animal Science, Gadjah Mada University.

\section{REFERENCES}

Chikuni, K., T. Nagatsuma, T.Tabata, M. Monma, M. Saito, S.Ozawa, and K. Ozutsumi, 1994. Genetics variants of the growth hormone gene in Japanese cattle. J. Anim. Sci. Technol. 65: 340-346

Dario, C., D. Carnicella and G. Bufano, 2005. A note on the growth hormone (GH1-AluI) polymorphism in Podolian cattle in Sourthern Italy. J. Anim. Sci. Pap. Rep. 23(1):43-49

Hartatik, T., S.D. Volkandari, M.P. Rachman and Sumadi. 2013. Polymorphism leu/val of growth hormone gene identified from Limousin cross local cattle in Indonesia. Procedia Environmental Sci. 17:105-108

Lee, B.K., G.F. Lin, B.A. Crooker, M.P. Murtaugh, L.B. Hansen, H Chester-Jones, 1996. Association of somatotropin (bST) gene polymorphism at the 5th exon with selection for milk yield in Holstein cows. J. Domest. Anim. Endocrinol. 13(4): 373-381

Lucy, M. C., S. D. Hauser, P. J. Eppard, G. G. 
Krivi, J. H. Clark, D. E. Bauman and R. J. Collier, 1993. Variants of somatotropin in cattle: gene frequencies in major dairy breeds and associated milk yield. J. Domest. Anim. Endocrinol. 10(4):325-333

Mohammadabadi, M. R., A. Torabi, M. Tahmourespoor, A. Baghizadeh, A. E. Koshkoieh, and A. Mohammadi, 2010. Analysis of bovine growth hormone gene polymorphism of local and Holstein cattle breeds in Kerman province of Iran using PCR-RLFP. Afr. J. Biotechnol. 9(41):68486852

Mu'in, M. A. 2008. Polimorfisme Genetik Growth Hormone dan Insuline-like Growth Factor-I serta Efeknya pada pertumbuhan Prasapih Sapi Potong di Indonesia. Disertasi. Faculty of Animal Science, Gadjah Mada University, Yogyakarta.

Mu'in, M.A. dan N. Zurahmah. 2007. Evaluasi polimorfisme Leu/Val pada gen hormone pertumbuhan sapi Friesian Holstein di Balai Pembibitan Ternak Unggul Sapi Perah Baturraden. Anim. Prod. 11(3):155-159

Pawar, R. S., K. R. Tajane, C. G. Joshi, D. N. Rank and B.P. Bramkshtri, 2007. Growth hormone gene polymorphism and its association with lactation yield in dairy cattle. Indian. J. Anim. Sci. 77(9):884-888
Reis, C., D. Navas, M. Pereira and A. Cravador. 2001. Growth hormone Alu I polymorphism analysis in eight portuguese bovine breeds. Arch. Zootec. 50:41-48

Sabour, M. P., C. Y. Lin, and C. Smith. 1997. Association of genetic variants of bGH with milk yield traits in Holstein cattle. J. Anim. Breed. Genet. 114: 435-442

Sambrook, J., E. F. Fritsch and T. Maniatis. 1989. Molecular cloning, a laboratory manual. Cold Spring Harbour Laboratory Press: Cold Spring Harbour, USA.

Vukasinovic, N., S. K. Denise and A. E. Freeman. 1999. Association of growth hormone loci with milk yield traits in Holstein Bulls. J. Dairy Sci. 82:788-794

Yao, J., S.E. Anggerey, D. Zadworny, J. F. Hayes and U. Kuhnlein. 1996. Sequence variations in the bovine growth hormone gene characterized by single-strand conformation polymorphism (SSCP) analysis and their association with milk yield traits in Holstein. Genetics. 144:1809-1816

Zhang, R. F., H. Chen, C. Z. Lei1, X. T. Fang, Y. D. Zhang, S. R. Hu and L. H. Su. 2007. Association between PCR-RFLP polymorphisms of five gene loci and milk traits in Chinese Holstein. Asian-Aust. J. Anim. Sci.20(2):166-171 